Огляди літератури, оригінальні дослідження, погляд на проблему, випадок з практики, короткі повідомлення удК 616. 137.83/93-005.4-089.319.5-06.6:612.121.3

DOI 10.11603/1811-2471.2020.v.i2.11315

\title{
ПРОФІЛАКТИКА РЕПЕРФУЗІЙНО-РЕОКСИГЕНАЦІЙНОГО СИНДРОМУ У ПАЦІЄНТІВ ІЗ ХРОНІЧНОЮ КРИТИЧНОЮ ІШЕМІЕЮ НИЖНІХ КІНЦІВОК ШЛЯХОМ КОРЕКЦІЇ КИСЛОТНО-ОСНОВНОГО СТАНУ КРОВІ
}

\section{ФН. І. Герасимюк, І. І. Лойко}

Тернопільський національний медичний університет імені І. Я. Горбачевського МОЗ України

РЕЗЮМЕ. Хірургічне лікування хронічної артеріальної недостатності полягає в проведенні реконструктивних втручань на магістральному артеріальному руслі нижніх кінцівок. Порушенням кислотно-лужного балансу при реоксигенації ішемізованої кінцівки не надається достатньої уваги при лікуванні реперфузійно-реоксигенаційного синдрому.

Мета - покращити ефективність запобігання реперфузійно-реоксигенаційному синдрому в пацієнтів із хронічною критичною ішемією нижніх кінцівок шляхом медикаментозної корекції кислотно-лужного балансу крові.

Матеріал і методи. Дослідження проводили загалом у 79 пацієнтів із атеросклеротичним ураженням аортоклубово-стегнового сегмента. Оцінку кислотно-лужного балансу крові проводили на мікрогазоаналізаторі ABL-330 "Radiometer" та "Stat ProfAile ultrac". 30 пацієнтів із високим ризиком розвитку РPC були прооперовані після проведення підготовки, доповненої препаратом для корекції кислотно-лужного балансу крові (Трометамол).

Результати. Рівень рН венозної крові ішемізованої нижньої кінцівки у пацієнтів із ІІБ стадією ХАН знаходиться в межах, що відповідає компенсованому, із IIIA стадією - субкомпенсованому, із IIIБ - IV стадією - декомпенсованому метаболічному ацидозу. У них встановлено помітне, порівняно з контрольною групою, зниження $\mathrm{H} \mathrm{CO}_{3} \mathrm{i}$ SBC. При цьому вміст SBC нижчий у $1,4(p<0,05)$ раза, а Н CO - у $1,3(p<0,05)$ раза, порівняно зі здоровими особами. Найсуттєвіші зміни КЛБ спостерігаються у пацієнтів із ІІІБ - IV стадією ХАН. Використання Трометамолу дає можливість вже напередодні оперативного втручання підвищити $\mathrm{pH}$ до рівня 7,21 од., парціальний тиск $\mathrm{P} \mathrm{CO}_{2}$ та вміст в крові Т СО , ббільшити у 1,6 раза $\left(\right.$ <<0,05) вміст у венозній крові SBC та у 1,4 раза $(p<0,05)$ вміст $\mathrm{H} \mathrm{CO}_{3}$.

Висновки. Корекція кислотно-лужного балансу $\epsilon$ необхідною умовою запобігання реперфузійному пошкодженню при реваскуляризації артеріального русла нижніх кінцівок у пацієнтів із ХАН.

КлючОВІ СЛОВА: артеріальна недостатність; реперфузійний синдром.

Вступ. Ураження магістральних артерій нижніх кінцівок оклюзивного походження складають близько 1/5 всіх патологічних змін системи кровообігу [1]. Лікування хронічної артеріальної недостатності полягає в проведенні реконструктивних втручань на магістральному артеріальному руслі нижніх кінцівок [2]. Технічно бездоганні оперативні втручання не гарантують збереження ішемізованої нижньої кінцівки і відновлення периферійного кровотоку [3]. Відновлення кровотоку в цій ділянці супроводжується розвитком комплексу пов'язаних реакцій в ішемізованій нижній кінцівці $[4,5]$. Ці патологічні зміни призводять до постішемічного збіднення перфузії тканин м'язів гомілки із їх реперфузійним пошкодженням [5]. Пусковим фактором розвитку реперфузійно-реоксигенаційного синдрому $\epsilon$ поступлення в ішемізовані тканини кисню [6]. Невідповідність між кількістю кисню в артеріальній крові і можливістю тканин до його утилізації $є$ основним чинником цього процесу [7]. Це $\epsilon$ наслідком таких факторів: порушення в системі кисневотранспортної функції крові, балансу електролітів крові, прооксидантно-антиоксидантної рівноваги та кислотно-лужного балансу $[3,9]$. Порушенню кислотнолужного балансу у цьому патофізіологічному ланцюгу, за даними літератури, не надається до- статньої уваги при лікуванні реперфузійно-реоксигенаційного синдрому [10].

Мета - покращити ефективність запобігання реперфузійно-реоксигенаційному синдрому в пацієнтів із хронічною критичною ішемією нижніх кінцівок шляхом корекції кислотно-лужного балансу крові.

Матеріал і методи дослідження. Всі пацієнти були прооперовані. У 52 спостереженнях проведено аорто-біфеморальне алошунтування, у 17 з них одночасно проведено стегно-дистальне аутовенозне шунтування, у 27 пацієнтів проведено однобічне аорто-клубово-стегнове алошунтування, у 6 з них одночасно здійснено стегно-дистальне аутовенозне шунтування. 30 пацієнтів із високим ризиком розвитку РРС були прооперовані після проведення підготовки, доповненої середником для корекції кислотно-лужного балансу крові (КЛБ) (Трометамол). Кількість препарату для застосування була однаковою (в мл 0,3 моль/л розчину) = М (маса тіла в кг) × ВЕ (дефіцит основи в ммоль/л). Для попередження та лікування РPС Трометамол застосовували за дві доби до хірургічного втручання і в перші 2-3 доби раннього післяопераційного періоду. Дослідження проводили загалом у 79 пацієнтів із атеросклеротичним ураженням аортоклубово-стегнового сегмента. У контрольній групі 
Огляди літератури, оригінальні дослідження, поглядн на було 22 особи без ознак атеросклеротичного ураження кінцівок. Оцінку кислотно-лужного балансу крові (КЛБ) проводили на мікрогазоаналізаторі ABL-330 «Radiometer» (Данія) та «Stat ProfAile ultrac» (США). Для дослідження забір крові проводили до хірургічного втручання, на 1, 3 і 5 добу раннього післяопераційного періоду. Обробку результатів дослідження проведено за критеріями варіаційної статистики з використанням програм EXEL i STATISTIC.

Результати й обговорення. При аналізі показників КЛБ крові із підшкірної вени ішемізованих нижніх кінцівок у пацієнтів із атеросклеротичним ураженням аорто-клубово-стегнового сегмента встановлено його зміну в сторону метаболічного ацидозу. До показників, які визначають характер зсуву КЛБ у хворих, належить зниження рН венозної крові. У пацієнтів із ІІБ стадією ХАН величина рН венозної крові ішемізованої нижньої кінцівки знаходиться в межах, що відповідають компенсованому метаболічному ацидозу. Зсув рН венозної крові у пацієнтів цієї групи відбувається завдяки зниженню буферних систем організму як результат ішемії в нижніх кінцівках та підвищеному вмісту продуктів анаеробного обміну речовин. У хворих із ІІБ стадією ХАН встановлено помітне, порівняно із контрольною групою, зниження $\mathrm{H} \mathrm{CO}_{3}$ i SBC. У пацієнтів із ІІІА стадією ХАН рівень рН венозної крові ішемізованої нижньої кінцівки визначається в межах субкомпенсованого метаболічногоу ацидозу. При вказаних обставинах вміст SBC нижчий у 1,4 $(p<0,05)$ раза, а $\mathrm{H} \mathrm{CO}_{3}$ - у 1,3 $(p<0,05)$ раза, порівняно зі здоровими обстеженими. Падіння концентрації бікарбонатів призводить до дефіциту буферних ос- лему, випадок з практики, короткі повідомлення нов і свідчить про нагромадження нелетких органічних кислот в організмі хворих із атеросклеротичним ураженням артеріального русла нижніх кінцівок.

Найпомітніші зміни КЛБ були у пацієнтів із ІІІБIV стадією ХАН. Рівень рН венозної крові ішемізованої нижньої кінцівки у хворих із даною стадією ХАН знаходиться в межах декомпенсованого метаболічного ацидозу. Вміст SBC нижчий у 1,7 $(p<0,001)$ раза, а $\mathrm{H} \mathrm{CO}_{3}$ - у 1,6 ( $\left.<<0,05\right)$ раза, порівняно з контрольною групою. При цьому відбувається виражене зміщення буферних основ і зниження вмісту бікарбонатів. Дефіцит буферних основ у венозній крові ішемізованої нижньої кінцівки в 9 разів перевищує їх рівень в осіб контрольної групи.

У 13 пацієнтів із ІІІБ-IV стадією ХАН і ризиком розвитку реперфузійно-реоксигенаційного синдрому (РPC) реконструкція аорто-клубово-стегнового сегмента здійснювалась після проведення системної підготовки з метою профілактики та лікування РPС без корекції КЛБ [9]. Показники КЛБ у першу добу раннього післяопераційного періоду вказували на поглиблення декомпенсованого ацидозу (табл. 1). Поряд із несуттєвим зниженням рівня рН венозної крові проблемної нижньої кінцівки спостерігалося достовірне ( $<<0,05)$ зниження як $\mathrm{PCO}_{2}$, так і тCO 2 . Вміст SBC був на 19,2 \% нижчий, а вміст $\mathrm{H} \mathrm{CO}_{3}$ незначно вищий (5,6 \%), порівняно із показниками, отриманими напередодні оперативного втручання. Відбувався більш виражений зсув буферних основ, падіння вмісту бікарбонатів. Дефіцит буферних основ у венозній крові проблемних нижніх кінцівок майже у 10 разів перевищував їх рівень в осіб контрольної групи.

Таблиця 1. Зміна показників кислотно-лужного балансу крові при реваскуляризації артеріального русла нижньої кінцівки у пацієнтів із ризиком розвитку реперфузійно-реоксигенаційного синдрому

\begin{tabular}{|l|c|c|c|c|c|c|}
\hline \multirow{2}{*}{$\begin{array}{c}\text { Строки } \\
\text { операційного } \\
\text { процесу }\end{array}$} & \multicolumn{5}{|c|}{ Показники } \\
\cline { 2 - 7 } & $\mathrm{PH,} \mathrm{од.}$ & $\begin{array}{c}\mathrm{P} \mathrm{CO}_{2^{\prime}} \\
\text { мм рт. Ст. }\end{array}$ & $\begin{array}{c}\mathrm{T} \mathrm{CO}_{2^{\prime}} \\
\text { мМоль/л }\end{array}$ & $\begin{array}{c}\mathrm{SBE} \\
\text { мМоль/л }\end{array}$ & $\begin{array}{c}\mathrm{SBC} \\
\text { мМоль/л }\end{array}$ & $\begin{array}{c}\mathrm{HCO}_{3^{\prime}} \\
\text { мМоль/л }\end{array}$ \\
\hline До операції & $7,04 \pm 0,05$ & $38,17 \pm 0,91$ & $17,41 \pm 0,83$ & $-16,17 \pm 2,15$ & $11,53 \pm 2,28$ & $14,56 \pm 2,34$ \\
\hline $\begin{array}{l}1 \text { доба після } \\
\text { операції }\end{array}$ & $7,02 \pm 0,11$ & $\begin{array}{c}34,16 \pm 1,53 \\
<0,05\end{array}$ & $\begin{array}{c}14,72 \pm 0,98 \\
<0,05\end{array}$ & $-17,82 \pm 3,04$ & $9,27 \pm 2,08$ & $15,41 \pm 2,44$ \\
\hline $\begin{array}{l}3 \text { доба після } \\
\text { операції }\end{array}$ & $7,22 \pm 0,08$ & $36,28 \pm 1,95$ & $17,81 \pm 0,94$ & $-15,24 \pm 2,75$ & $11,51 \pm 2,32$ & $\begin{array}{c}19,32 \pm 2,51 \\
<0,05\end{array}$ \\
\hline $\begin{array}{l}5 \text { доба після } \\
\text { операції }\end{array}$ & $\begin{array}{c}7,24 \pm 0,07 \\
<0,05\end{array}$ & $39,42 \pm 2,09$ & $22,83 \pm 1,36$ & $-8,17 \pm 1,53$ & $\begin{array}{c}17,63 \pm 2,47 \\
<0,05\end{array}$ & $\begin{array}{c}22,59 \pm 2,53 \\
<0,05\end{array}$ \\
\hline
\end{tabular}

Зазначене вище свідчить про необхідність передопераційної корекції КЛБ. 36 пацієнтам із IIIБ-IV стадією ХАН і ризиком розвитку РPC реконструкцію аорто-клубово-стегнового сегмента здійснювали після проведення системної підготовки з метою профілактики та лікування РPС [9] та корекції КЛБ препаратом Трометамол (табл. 2). Дослідження КЛБ, проведені до оперативного втручання, встановили значні зміни в його стані.
Разом з підвищенням рН до рівня 7,21 од. зростали показники $\mathrm{P} \mathrm{CO}_{2}$ та вміст в крові $\mathrm{T} \mathrm{CO}_{2}$, збільшувався у 1,6 раза $(p<0,05)$ вміст у венозній крові SBC, у 1,4 раза $(p<0,05)$ вміст у венозній крові $\mathrm{H} \mathrm{CO}$. Реваскуляризація артеріального русла у пацієнтів із ІІІБ-IV стадією ХАН несуттєво сприяла зниженню рівня КЛБ. А вже на 5 добу поопераційного періоду рівень КЛБ досяг величин здорових oci6. 
Огляди літератури, оригінальні дослідження, погляд на проблему, випадок з практики, короткі повідомлення

Таблиця 2. Зміна показників кислотно-лужного балансу крові при реваскуляризації артеріального русла нижньої кінцівки у пацієнтів із ризиком розвитку реперфузійно-реоксигенаційного синдрому при застосуванні корегуючої терапії

\begin{tabular}{|l|c|c|c|c|c|c|}
\hline \multirow{2}{*}{$\begin{array}{c}\text { Строки } \\
\text { операційного } \\
\text { процесу }\end{array}$} & $\mathrm{PH,} \mathrm{од.}$ & $\begin{array}{c}\mathrm{P} \mathrm{CO}_{2^{\prime}} \\
\text { мм Рт. Ст. }\end{array}$ & $\begin{array}{c}\mathrm{T} \mathrm{CO}_{2^{\prime}} \\
\text { мМоль/л }\end{array}$ & $\begin{array}{c}\mathrm{SBE} \\
\text { мМоль/л }\end{array}$ & $\begin{array}{c}\mathrm{SBC} \\
\text { мМоль/л }\end{array}$ & $\begin{array}{c}\mathrm{H} \mathrm{CO}_{3^{\prime}} \\
\text { мМоль/л }\end{array}$ \\
\cline { 2 - 7 } & $7,21 \pm 0,06$ & $41,45 \pm 1,34$ & $19,47 \pm 0,91$ & $-11,38 \pm 1,83$ & $17,76 \pm 2,41$ & $19,63 \pm 2,68$ \\
\hline $\begin{array}{l}\text { До операції } \\
\text { доба після }\end{array}$ & $7,18 \pm 0,08$ & $39,64 \pm 1,31$ & $22,92 \pm 1,15$ & $-7,53 \pm 1,24$ & $15,84 \pm 2,37$ & $17,08 \pm 1,76$ \\
\hline $\begin{array}{l}\text { операції } \\
\text { опера після }\end{array}$ & $7,24 \pm 0,08$ & $38,52 \pm 1,58$ & $23,45 \pm 1,32$ & $\begin{array}{c}-6,75 \pm 1,29 \\
<0,05\end{array}$ & $18,16 \pm 2,41$ & $19,15 \pm 1,96$ \\
\hline $\begin{array}{l}5 \text { доба після } \\
\text { операції }\end{array}$ & $7,33 \pm 0,07$ & $41,82 \pm 2,25$ & $24,53 \pm 1,47$ & $\begin{array}{c}-3,52 \pm 0,76 \\
<0,05\end{array}$ & $22,83 \pm 2,64$ & $23,71 \pm 2,34$ \\
\hline
\end{tabular}

ХАН нижніх кінцівок знаходиться у тісній взаємодії із реакцією середовища організму, зокрема із кислотно-лужним балансом крові [3]. КЛБ впливає на всі функції організму, насамперед на кислотнотранспортну функцію крові [8]. КЛБ венозної крові ішемізованої нижньої кінцівки у пацієнтів із ураженням аорто-клубово-стегнового сегмента при наростанні ступеня ХАН зміщується в сторону метаболічного ацидозу. Рівень рН венозної крові ішемізованої нижньої кінцівки у пацієнтів із ІІБ стадією ХАН знаходиться в межах, що відповідають компенсованому метаболічному ацидозу. У них встановлено помітне, порівняно із групою здорових осіб, зниження $\mathrm{H} \mathrm{CO}_{3}$ і SBC. Рівень же $\mathrm{pH}$ венозної крові ішемізованої нижньої кінцівки у пацієнтів із IIIA стадією ХАН знаходиться в межах, що відповідають вже субкомпенсованому метаболічному ацидозу. При цьому вміст SBC нижчий у $1,4(p<0,05)$ раза, а $\mathrm{H} \mathrm{CO}_{3}$ - у $1,3(\mathrm{p}<0,05)$ раза, порівняно зі здоровими особами. Найвираженіші зміни КЛБ спостерігаються у пацієнтів із ІІІБ-IV стадією ХАН. При цьому відбувається виражений зсув буферних основ і зниження вмісту бікарбонатів, а рівень $\mathrm{pH}$ венозної крові ішемізованої нижньої кінцівки у хворих із цією стадією ХАН знаходиться в межах декомпенсованого метаболічного ацидозу.

У пацієнтів із ІІІБ-IV стадією ХАН реваскуляризація артеріального русла нижніх кінцівок у ранньому післяопераційному періоді поглиблює прояв декомпенсованого ацидозу [3]. Причиною поглиблення декомпенсації метаболічного аци-

\section{ЛІТЕРАТУРА}

1. Калинин Р. Е. Эндотелиальная дисфункция и способы ее коррекции при облитерирующем атеросклерозе / Р. Е. Калинин, И. А. Сучков, А. С. Пшенникова. - М. : ГЕОТАР-Медиа, 2014. - 152 с.

2. Percival T. J. Reperfusion strategies in the management of extremity vascular injury with ischaemia / T. J. Percival, T. E. Rasmussen. // British Journal of Surgery 2012. Vol. 99 (Suppl 1). - P. 66-74. дозу слід вважати розлади кислотнотранспортної функції крові, як результат поступлення в ішемізовані тканини збагаченої киснем крові [2]. Це сприяє утворенню недоокиснених продуктів обміну, що спонукають до ще більшого зсуву КЛБ у кислий бік [3].

Необхідно проводити реваскуляризацію артеріального русла нижніх кінцівок у пацієнтів із ІІІБIV стадією ХАН при ризику розвитку РPC на фоні системної підготовки з метою профілактики та лікування РРС одночасно із корекцєю КЛБ $[8,10]$. Саме такий підхід до вирішення питання дає можливість вже напередодні оперативного втручання підвищити рН до рівня 7,21 од., парціальний тиск P $\mathrm{CO}_{2}$ та вміст в крові Т $\mathrm{CO}_{2}$ збільшити у 1,6 раза $(p<0,05)$ вміст у венозній крові SBC та у 1,4 раза $(p<0,05)$ вміст $\mathrm{H} \mathrm{CO}_{3}$. Оперативне втручання сприяє несуттєвому зниженню рівня рівня КЛБ, а на 5 добу післяопераційного періоду рівень КЛБ досягає величин осіб контрольної групи.

Висновки. У пацієнтів із атеросклеротичним ураженням нижніх кінцівок кислотно-лужний баланс венозної крові змінюється у напрямку метаболічного ацидозу і не нормалізується у ранньому післяопераційному періоді після реконструктивних операцій.

Корекція кислотно-лужного балансу $\epsilon$ необхідною умовою попередження реперфузійного пошкодження при реваскуляризації артеріального русла нижніх кінцівок у пацієнтів із хронічною артеріальною недостатністю. 
Огляди літератури, оригінальні дослідження, погляд на проблему, випадок з практики, короткі повідомлення сов // Регионарное кровообращение и микроциркуляция. - 2017. - № 16 (1). - С. 4-15.

6. Mitochondrial quality control and disease: Insights into ischemia-reperfusion injury / A. R. Anzell, R. Maizy, K. Przyklenk, T. H. Sanderson // Mol. Neurobiol. - 2018. Vol. 55. - P. 2547-2564.

7. Santistevan J. R. Acute limb ischemia: an emergency medicine approach / J. R. Santistevan // Emerg. Med. Clin. North Am. - 2017. - Vol. 35. - P. 889-909.

8. The effect of antioxidants on ischemia-reperfusion injury in flap surgery, antioxidants, emad shalaby / Mehmet

Bozkurt, Melihcan Sezgic, Percin Karakol [et al.] // Intech. Open. DOI: 10.5772/intechopen.85500.

9. Eltzschig H. K. Ischemia and reperfusion - from mechanism to translation / H. K. Eltzschig, T. Eckle // Nat. Med. - 2011. - Vol. 17. - P. 1391-401.

10. Профілактика та лікування реперфузійного пошкодження тканин при реконструкції артеріального русла аорто-стегно-підколінного сегмента в умовах хронічної критичної ішемії / І. К. Венгер, О. Б. Колотило, С. Я. Костів [та ін.] // Шпитальна хірургія. - 2018. - № 3. С. $75-77$.

\section{REFERENCES}

1. Kalinin, R.E., Suchkov, Y.A., \& Pshennikova, A.S. (2014). Endotelialnaya disfunktsiya i sposoby ee korrektsii pri obliteriruyushchem ateroskleroze [Endothelial dysfunction and methods for its correction in obliterating atherosclerosis]. Moscow: GEOTAR-Media [in Russian].

2. Percival, T.J., \& Rasmussen, T.E. (2012). Reperfusion strategies in the management of extremity vascular injury with ischaemia. British Journal of Surgery, 99 (Suppl. 1), 66-74.

3. Henyk, S.M., \& Symchych, A.V. (2016). Reperfuziinyi syndrom pislia revaskuliaryzatsii ishemii nyzhnikh kintsivok [Reperfusion syndrome after revascularization of lower extremity ischemia]. Sertse i sudyny - Heart and Vessels, 3,104-108 [in Ukrainian].

4. Inter-society consensus for the management of peripheral arterial disease (TASC II). J. Vasc. Surg., 45, 5-67.

5. Vasina, L.V., Petryshhev, N.N., \& Vlasov, T.D. (2017). Endotelialnaya disfunktsiya i ee osnovnye marker [Endothelial dysfunction and its main markers]. Regionarnoe krovoobrashcheniye i mikrotsyrkulyatsiya - Regional Blood Circulation and Microcirculation, 16 (1), 4-15 [in Russian].

6. Anzell, A.R., Maizy, R., Przyklenk, K., \& Sanderson T.H. (2018). Mitochondrial quality control and disease:

Insights into ischemia reperfusion injury. Mol. Neurobiol., $55,2547-2564$

7. Santistevan, J.R. (2017). Acute limb ischemia: an emergency medicine approach. Emerg. Med. Clin. North Am., 35, 889-909.

8. Mehmet Bozkurt, Melihcan Sezgic, Percin Karakol, Can Uslu, Tevfik Balikci, \& Emad Shalaby (2019). The effect of antioxidants on ischemia-reperfusion injury in flap surgery, antioxidants. Intech. Open. DOI: 10.5772/intechopen. 85500 .

9. Eltzschig, H.K., \& Eckle, T. (2011). Ischemia and reperfusion - from mechanism to translation. Nat. Med., 17, 1391-1401.

10. Venher, I.K., Kolotylo, O.B., Kostiv, S.Ya., Vaida, A.R., \& Herasymiuk, N.I. (2018). Profilaktyka ta likuvannia reperfuziinoho poshkodzhennia tkanyn pry rekonstruktsii arterialnoho rusla aorto-stehno-pidkolinnoho sehmenta v umovakh khronichnoi krytychnoi ishemii [Prevention and treatment of reperfusion tissue damage in the reconstruction of the arterial bed of the aorto-femoral-popliteal segment in conditions of chronic critical ischemia]. Shpytalna khirurhiia - Hospital Surgery, 3, 75-77 [in Ukrainian].

\section{ПРОФИЛАКТИКА РЕПЕРФУЗИОННО-РЕОКСИГЕНАЦИОННОГО СИНДРОМА У ПАЦИЕНТОВ С ХРОНИЧЕСКОЙ КРИТИЧЕСКОЙ ИШЕМИЕЙ НИЖНИХ КОНЕЧНОСТЕЙ ПУТЕМ КОРРЕКЦИИ КИСЛОТНО-ЩЕЛОЧНОГО СОСТОЯНИЯ КРОВИ}

๑Н. И. Герасимюк, И. И. Лойко

Тернопольский национальный медицинский университет имени И. Я. Горбачевского мОз Украины

РЕЗЮМЕ. Хирургическое лечение хронической артериальной недостаточности заключается в проведении реконструктивних вмешательств на магистральном артериальном русле нижних конечностей. Нарушениям кислотно-щелочного баланса при реоксигенации ишемизированной конечности не предоставляется достаточного внимания при лечении реперфузионно-реоксигенационного синдрома.

Цель - повысить эффективность предупреждения реперфузионно-реоксигенационного синдрома у пациентов с хронической критической ишемией нижних конечностей путем медикаментозной коррекции кислотно-щелочного баланса крови.

Материал и методы. Исследование проводилось на 79 пациентах с атеросклеротическим поражением аортоподвздошно-бедренного сегмента. Оценку кислотно-щелочного баланса крови проводили на микрогазоанализаторах ABL-330 "Radiometer" и "Stat ProfAile ultrac". 30 пациентов с высоким риском развития PРC были прооперированы после проведения подготовки, дополненной препаратом для коррекции кислотно-щелочного баланса крови (Трометамол).

Результаты исследования. $\mathrm{pH}$ венозной крови ишемизированной нижней конечности у пациентов с ІІБ стадией ХАН находится в пределах, соответствующих компенсированному, с IIIA стадией - субкомпенсированному, с 
Огляди літератури, оригінальні дослідження, погляд на проблему, випадок з практики, короткі повідомлення IIIB - IV стадией - декомпенсированному метаболическому ацидозу. У них установлено заметное, по сравнению с контрольной группой, снижение $\mathrm{H} \mathrm{CO}_{3}$ и SBC. При этом содержание SBC было ниже в 1,4 (р<0,05) раза, а Н CO С $_{3}$ в 1,3 $(p<0,05)$ раза по сравнению с здоровыми лицами. Наиболее существенные изменения КЛБ наблюдаются у пациентов с IIIB - IV стадией ХАН. Использование Трометамола дает возможность уже накануне оперативного вмеша-

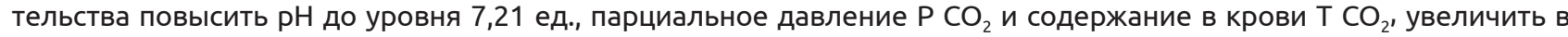
1,6 раза $(p<0,05)$ содержание в венозной крови SBC и в 1,4 раза $(p<0,05)$ содержание $\mathrm{H} \mathrm{CO}_{3}$.

Выводы. Корекция кислотно-щелочного баланса является необходимым условием предупреждения реперфузионного повреждения при реваскуляризации артериального русла нижних конечностей у пациентов с ХАН.

КЛючЕВЫЕ СЛОВА: артериальная недостаточность; реперфузионный синдром.

\section{PREVENTION OF REPERFUSION-REOXYGENATION SYNDROME IN PATIENTS WITH CHRONIC CRITICAL ISCHEMIA OF THE LOWER EXTREMITIES BY CORRECTION OF ACID-ALKALINE STATUS OF BLOOD}

\section{Horbachevsky Ternopil National Medical University}

SUMMARY. Surgical treatment of chronic arterial insufficiency consists in reconstructive interventions on the main arterial bed of the lower extremities. Not enough attention is paid to disruption of acid-base balance in reoxygenation of the ischemic limb in the treatment of reperfusion-reoxygenation syndrome.

The aim - to improve the effectiveness of prevention of reperfusion-reoxygenation syndrome in patients with chronic critical ischemia of lower extremities by correction of acid-base balance of the blood.

Material and Methods. The study was performed in a total of 79 patients with atherosclerotic lesions of the aorto/ iliac-femoral segment. Assessment of acid-base balance of blood was performed on a microgas analyzer ABL - 330 “Radiometer" and "Stat ProfAile ultrac". Thirty patients at high risk of developing RRS were operated after preop care supplemented by the medication to correct acid-base balance (Trometamol).

Results and Discussion. The $\mathrm{pH}$ level of venous blood of the ischemic lower extremity in patients with stage IIB of CAI is in the range that corresponds to compensated, with stage IIIA - subcompensated, with stage IIIB-IV - decompensated metabolic acidosis. A noticeable, compared with the control group, decrease in $\mathrm{H} \mathrm{CO}_{2}$ and SBC was found. The content of SBC is 1.4 times lower $(p<0.05)$, and $\mathrm{H} \mathrm{CO}_{2}-1.3(p<0.05)$ times lower compared to healthy individuals. The most significant changes in AAB are observed in patients with stage IIIB-IV CAI. The use of Trometamol makes it possible to increase partial pressure $\mathrm{PCO}_{2}$ and $\mathrm{TCO}_{2}$ in blood, $\mathrm{pH}$ up to 7.21 units, and 1.6 times $(\mathrm{p}<0.05)$ increase of the contents of $\mathrm{SBC}$ in venous blood and 1.4 times $(p<0,05)$ of $\mathrm{H} \mathrm{CO}_{3}$ contents.

Conclusions. Correction of acid-alkaline balance is necessary for the prevention of reperfusion injury during revascularization of the arterial bed of the lower extremities in patients with CAI.

KEY WORDS: arterial insufficiency; reperfusion syndrome. 